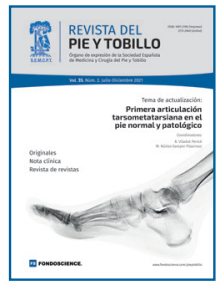

REVISTA DEL

Vol. 35. Núm. 2. Julio-Diciembre 2021

PIE Y TOBILLO

ISSN: 1697-2198 (impreso)

2173-2949 (online)

Sociedad Española de Medicina y Cirugía del Pie y Tobillo

\title{
Editorial
}

\section{Hacia una nueva normalidad}

\section{Towards a new normal}

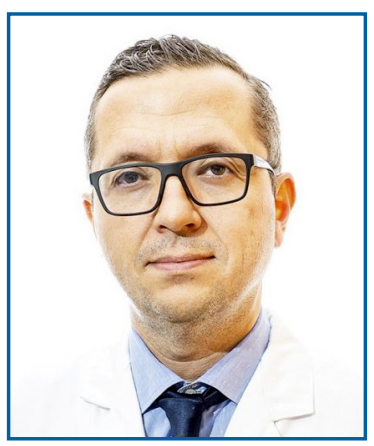

Dr. Mario Herrera Pérez Director de la Revista del Pie y Tobillo

\section{Estimados socios:}

Llega el final de este 2021 y parece que por fin la situación de pandemia se va atenuando. Atrás han quedado muchos meses de desasosiego y pérdidas humanas en nuestro entorno; también hemos perdido a compañeros en el mundo del pie y tobillo. Para todos ellos, nuestro recuerdo más sentido.

En este nuevo número del mes de diciembre del presente año tengo el placer de presentarles un tema de actualización novedoso por su extensión pero enormemente interesante. Coordinado por los senadores Ramón Viladot y Mariano Núñez Samper, realiza una actualización de la relevancia de la articulación tarsometatarsiana, a menudo poco considerada en la cirugía del pie. En este tema de actualización participan diferentes autores, socios de la SEMCPT, expertos en los diferentes subapartados de la misma, que completan una entrega científicamente impecable que seguro será útil para todos los lectores de nuestra revista.

Por otro lado, seguimos con las secciones habituales de nuestra revista, en un intento de recuperar la normalidad tras los malos tiempos que todos hemos vivido. Sin más, les animo como siempre a seguir participando con su colaboración científica en la Revista del Pie y Tobillo, con el único objetivo de seguir creciendo día a día en calidad y cantidad.

Feliz final de año a todos,

\section{Mario Herrera Pérez}

Director de la Revista del Pie y Tobillo

FS 